\title{
The Effect of Macroeconomics and Global Commodity Prices on Mining Index on Indonesia Stock Exchange for The Period of August 2016 - February 2019
}

\author{
Erly Mulyani' ${ }^{1}$, Fajar Akbari ${ }^{2}$ \\ ${ }^{1}$ Universitas Negeri Padang, Padang, Indonesia $\square$ erly1978@gmail.com \\ ${ }^{2}$ Universitas Negeri Padang, Padang, Indonesia $\bowtie$ fajarkhaikal@gmail.com
}

\begin{abstract}
This study aims to find out the effect of macroeconomics and global commodity prices on mining stock index. This study used causative method. The data used in this study comprised the data of monthly mining stock index, monthly exchange rate of Indonesian rupiah to US Dollar, monthly inflation, monthly oil price and monthly world gold price. There were 32month data used as the sample (August 2016 - February 2019). The data were analyzed using multiple linear regression. Based on the tests carried out, it was found that gold price, world oil price and exchange rate had a significant positive effect on mining stock index, while inflation did not significantly influence mining stock index.
\end{abstract}

Keywords: mining stock index, inflation, gold price, world oil, exchange rate

\section{Introduction}

Economic development today requires big amount of funding, one of the sources of funding comes from capital market. Along with the development of economy, capital market has experienced rapid development. Capital market can be used as an effective means of accelerating the development in a country. This is because capital market is a means to get funds from public to be channelled to various industrial sectors. In Indonesian capital market there are several sectors, one of which is mining sector.

Mining sector in Indonesia continues to experience fluctuations based on Figure 1.1. Based on the figure, the movement of mining sector stock price from August 2016 to February 2019 continued to fluctuate. Based on Figure 1.1, there were stock fluctuations in mining sector. Based on previous studies there are several factors that cause fluctuations in mining sector stock price, such as macroeconomics and global commodity prices. This study was conducted to determine the factors that cause fluctuations in mining stock index in Indonesia.

In globalization era, many investors choose to invest in mining sector, especially in gold. Gold is a global currency and its value is universally recognized. The intrinsic value is fixed and standard so that it can be bought and disbursed anywhere. Gold has a property not affected by inflation (zero inflation), so the price of gold always follows the movement of inflation. The increase in gold price will make investors more interested in investing in gold than stock. This situation makes the index fall because investors will sell their shares to switch to gold, and vice versa.

There are several studies that explain the factors that influence mining stock price index, including a study conducted by Rohmanda (2014) which found that inflation did not significantly influence the IHSG in mining sector, because inflation in Indonesia was included in low inflation category because its rate was less than $10 \%$ per year. Investors assume that the economy is still safe and they are still waiting for the government's policy to manage inflation rate. However, a study conducted by Darmawan (2018) discovered that inflation had a partial effect on mining stock index. In addition, based on a study conducted by Pardede and Sulasmiyati (2015), inflation simultaneously influenced mining stock index. 


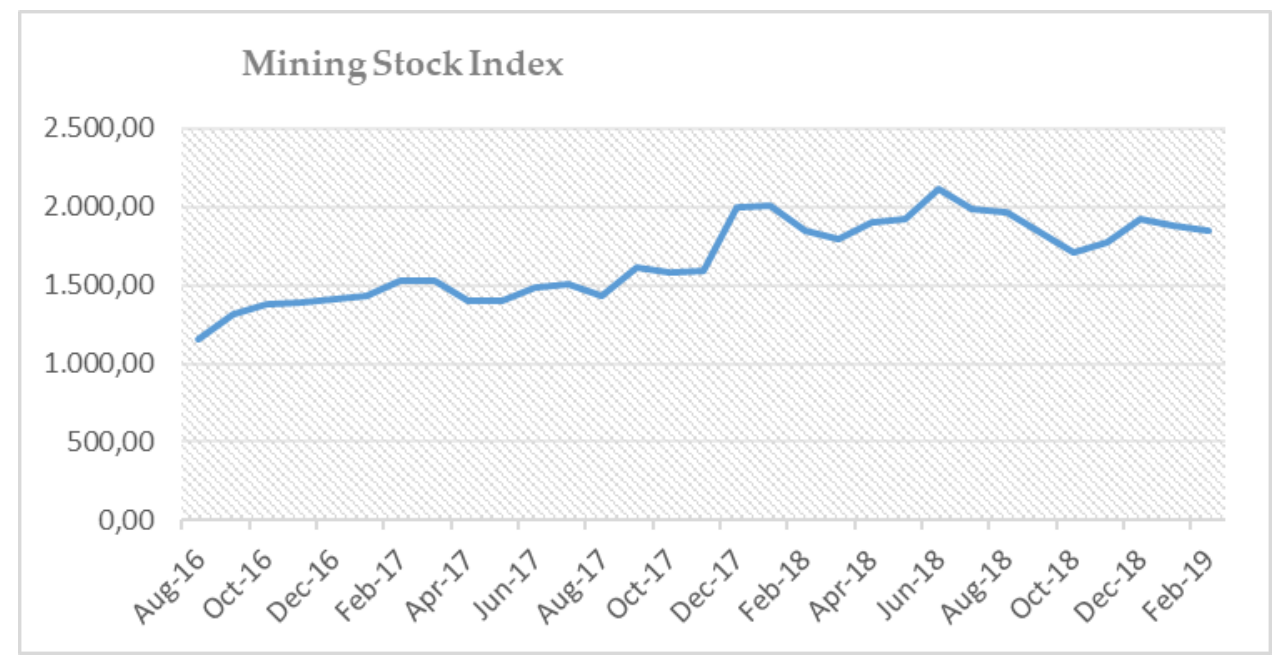

Source: Yahoo Finance, processed

Figure 1 Mining Stock Index Aug 2016-Feb 2019

Then, exchange rate also affects mining stock index, as found by (Pardede, 2015) in their study that exchange rate had a significant effect on the IHSG in mining sector. This was due to the depreciation of domestic currency, which indicated the weakening of the economy of country so as to provide an unfavorable effect on capital market. The occurrence of exchange rate depreciation in long term would make investors sell their shares because they did not want to experience large losses. The large number of stock sales from mining sector would cause the IHSG to decline. The results of the study are consistent with a study conducted by (Murcia, 2014).

The relationship between share and money market has been widely researched and debated academically in recent years (Rey, 2006). This can be understood because of the important role of capital market and exchange rate in economic activities (Akpan, 2008). Then, based on the result of a study conducted by (Yunita et al, 2018), exchange rate variable had a significant negative effect on mining index in Indonesia. This is in accordance with the idea of (Mardiyati , 2013) that such thing occurs because if the value of rupiah decreases, people will buy dollars, so capital market lacks attractiveness because the return on foreign currency purchases is higher than the purchase of shares. However, based on the result of a study conducted by Handiani (2014), exchange rate had a positive effect on Indonesia Composite Index (IHSG).

Furthermore, (Pardede, 2015) in their study found that world crude oil price had a simultaneous effect on the IHSG. Meanwhile, in (Darmawan, 2018) it was pointed out that world crude oil variable had no partial effect on the IHSG mining stock index. This result is in accordance with a study conducted by (Kurniawa, 2013) which showed that world oil price did not have a partial effect on the IHSG. Furthermore, Handiani (2014) in her study found that world oil price had a positive effect on IHSG.

Then, Darmawan (2018) in his study discovered that world gold price affected mining stock index in Indonesia. This was because gold was still being a community investment choice. If world gold price increased, mining stock index would increase. This is consistent with a study conducted by (Kurniawan, 2013), (Yunita et al, 2018) and (Kesuma, 2012). Furthermore, according to (Handiani, 2014) world gold price has a positive effect on IHSG.

According to (Hermann, 2015), industrial revolution is a collection of technology and value chain organizations in the forms of smart factory, CPS, IoT and IoS. Industrial revolution 4.0 that is happening today will provide benefits and influence economic development including capital market. At present, the rapid development of industrial revolution 4.0 has given the idea of integrating all these technologies into various industrial fields. Industry 4.0 provides many benefits but cannot be separated from the challenges that must be faced. According to (Qin, 2016) there are quite wide gaps in terms of technology 
across the world at this time with the expected condition in industry 4.0. A study conducted by (Balasingham, 2016) also showed that there was a factor of company reluctance to implement industry 4.0 because of concerns about the uncertainty of its benefits.

The purpose of this study is to describe the influence of macroeconomic factors, such as inflation and exchange rate, and global commodity prices, such as world gold price and world crude oil price, on mining stock index. This study is expected to be used by investors as a basis for decision making in selecting shares by taking into account the movement of Indonesia composite index.

Stock price index is an indicator that shows stock price movement. The index movement describes the market conditions when the market is active or slow (Darmadji, 2008). The index can be used as an indicator for investors in making investment decisions. According to (Rafique, 2014) capital market performance is measured using an index. Fluctuating index is influenced by various factors, including macroeconomic, political, social and company factors. Mining sector is one of the sectors found on Indonesia Stock Exchange which consists of coal, oil, natural gas and others.

Macroeconomics is a study of economy as a whole. Macroeconomic factors that need to be considered in capital market are inflation, interest rate and exchange rate of rupiah. According to (Madura, 2006) there are several factors that influence stock index including interest rate, exchange rate and inflation.

Inflation is a general increase in prices in the economy in a certain period of time (Nordhaus, 2001). Inflation can make profits and losses in the economy. The effect of inflation such as increasing production costs of a company will result in a decrease in company performance. Inflation is an overall increase in prices that occurs when prices rise simultaneously (Fair, 2007). Inflation is a continuous price increase that can affect individuals, entrepreneurs and government (Mishkin, 2010). Inflation can also be interpreted as a continuous and general increase in prices over a period of time (Bank Indonesia, 2018). In addition, inflation is a tendency of rising prices of goods and services that continue continuously. If the price of goods and services increases in a country, then inflation will occur (Central Statistical Agency, 2018).

According to Mankiw (2006) exchange rate is the price level agreed upon by residents of two countries to trade each other. According to Ekananda (2015) exchange rate is interpreted as the price of a currency which is relative to other countries' currency. This is because exchange rate includes two currencies. Nopirin (2000) states that exchange rate is a comparison of value or price between two currencies resulting from the exchange between two currencies. Sukirno (2006) mentions that foreign exchange rate shows the price or value of a country's currency expressed in the value of another country's currency. Exchange rate can also be defined as the amount of domestic money needed in foreign exchange market. Based on a study conducted by (Dar, M. Bhanja, 2014) it was found that exchange rate had a negative relationship with stock price.

Crude oil is one of the energy sources needed by every country in running the economy. Oil is used as a material for many industries in the world, so it is not surprising that the demand for oil will always be there at any time. Despite the high demand, oil reserves are increasingly decreasing. However, the world crude oil price benchmark uses Brent and WTI. World crude oil price affects all fields and industries, especially the companies that are directly related to crude oil commodityy. Nevertheless, a study conducted by (Kurniawan, 2013) found that world oil did not hae a partial effect on Indonesia composite index.

Gold is one of the mining products from the earth that has small investment risks. This is because the price of gold rarely decreases so that gold investment is often expected to get a higher return. Based on studies by (Handayani, 2014) and (Purnamasari, 2017), they conclude that if the price of gold rises, the return on mining stock index will increase. This happens because of the high demand for gold in Indonesia; therefore, the price of gold will tend to have a relationship with mining stock index. In addition, mining sector companies can increase profits from selling gold to people who invest gold for speculation. 


\section{Methods}

This study used causative method. Data were analyzed using multiple linear regression. The purpose of this study is to determine the effect of world gold price, world crude oil price West Texas Intermediate (WTI), exchange rate of rupiah to US Dollar and domestic inflation on mining stock index for the period of August 2016 - February 2019. Data sources used in this study were Yahoo Finance, Statistical Center Agency, Bank Indonesia and the website of investing.com.

Then, this study used saturation sampling. The sample used in this study were monthly data of world gold price, world crude oil price (WTI), exchange rate of Indonesian Rupiah to US Dollar, inflation and mining stock index in Indonesia for the period of August 2016 - February 2019. Data analysis techniques used were descriptive statistical analysis, inferential statistical analysis by conducting classical assumption test, multiple regression analysis and hypothesis testing. Multiple linear regression formula is as follows:

$$
Y_{\mathrm{t}}=\alpha \beta_{0}+\beta_{1} X_{1}+\log \beta_{2} X_{2}+\log \beta_{\mathrm{a}} X_{\mathrm{a}}+\beta_{4} X_{4}+\beta_{5} X_{5}+U_{\mathrm{t})}
$$

Legends:

$Y_{t} \quad$ : Mining Stock Index in Indonesia Period $t$

$\alpha \quad$ : Constant

b : Regression Coefficient

$\mathrm{X}_{1} \quad$ : World Gold Price

$\mathrm{X}_{2} \quad$ : World Oil Price

$X_{3} \quad$ : Exchange Rate

$\mathrm{X}_{4} \quad$ : Inflation

\section{Results and Discussion}

\section{Normality Test}

Normality test is carried out to find out whether dependent variable, independent variable or both are normally distributed, approaching normal or not (Umar, 2008). If probability value is $>0.05$, it means that it is normally distributed, whereas if probability value is $<0.05$, it means that the data are not normally distributed.

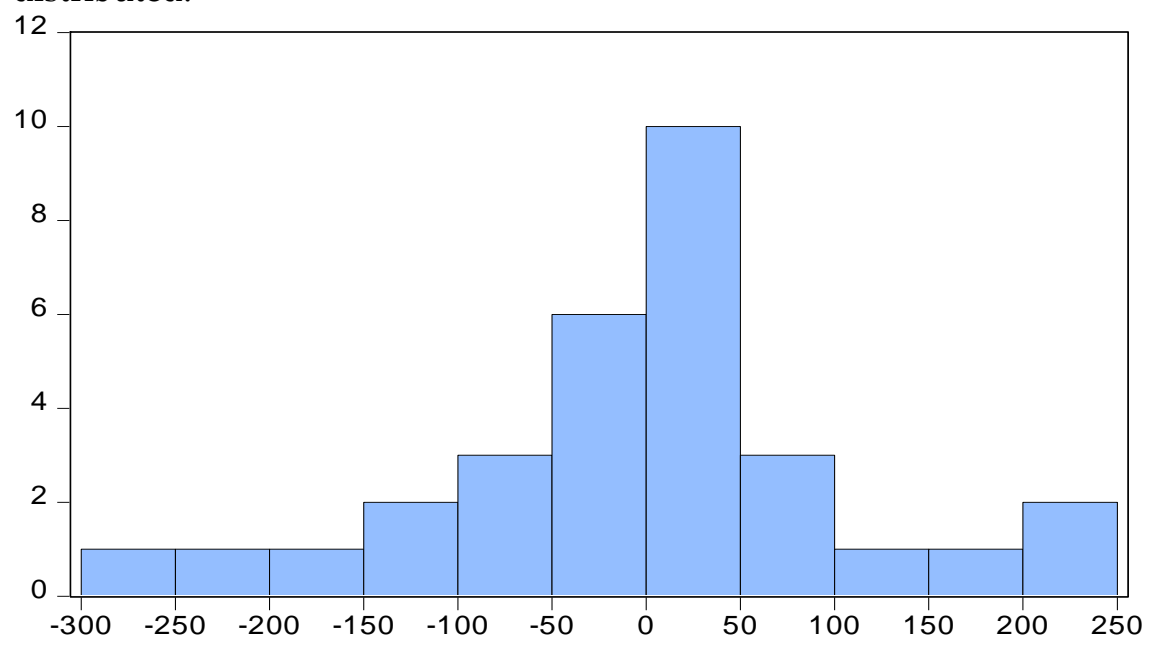

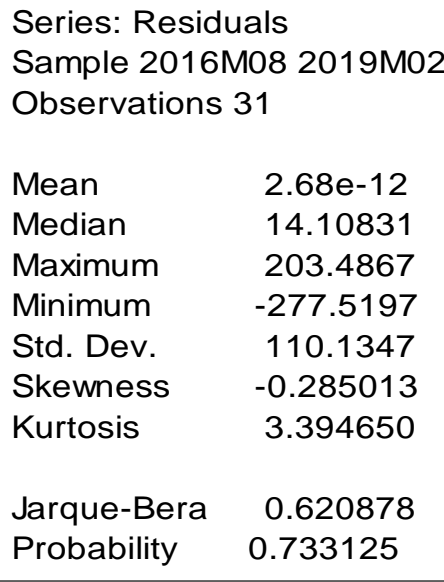

Source: Eviews Output Results, 2019

Figure 2 Normality Test 
The probability result from the normality test in this study was 0.7331 which can be seen in Figure 1.0. From the result of the test, the probability value was greater than 0.05 and the conclusion obtained in this study is that the data were normally distributed.

\section{Multicollinearity Test}

Multicollinearity test is used to find out whether a correlation among independent variables is found in the regression model (Umar, 2008). If a linear relationship among independent variables occurs, it will make the prediction of dependent variable biased. If the value of VIF (Variance Inflation Factor) $>10$ then multicollinearity does not occur and if the value of VIF is $<10$ then multicollinearity occurs. Based on Table 1, it can be concluded that multicollinearity did not occur among world gold price, world oil price, exchange rate and inflation because the value of $\mathrm{VIF} \leq 10$.

Table 1 Multicollinearity Test

\begin{tabular}{cccc}
\hline Variable & $\begin{array}{c}\text { Coefficient } \\
\text { Variance }\end{array}$ & $\begin{array}{c}\text { Uncentered } \\
\text { VIF }\end{array}$ & $\begin{array}{c}\text { Centered } \\
\text { VIF }\end{array}$ \\
\hline C & 33.71864 & 193288.6 & NA \\
\hline GOLD PRICE & 0.137532 & 40214.81 & 1.173801 \\
\hline WORLD OIL & 0.014486 & 1351.561 & 1.786334 \\
\hline EXCHANGE RATE & 0.230978 & 120258.6 & 1.985057 \\
\hline INFLATION & 0.002704 & 2.167796 & 1.067353 \\
\hline
\end{tabular}

Source: Eviews Output Results, 2019

\section{Autocorrelation Test}

Autocorrelation test is conducted to find out whether in a linear regression model there is a strong relationship both positive and negative among the data of research variables (Umar, 2008). Based on Table 1.2, autocorrelation test showed that there was no autocorrelation because the prob. Chi-Square value was greater than 0.05 or $0.2813 \geq 0.05$, so there was no autocorrelation in the data of this study.

Table 2 Autocorrelation Test

Breusch-Godfrey Serial Correlation LM Test:

\begin{tabular}{llll}
\hline F-statistic & 1.069374 & Prob. $F(2,24)$ & 0.3590 \\
\hline Obs $^{*}$ R-squared & 2.536509 & Prob. Chi-Square (2) & 0.2813 \\
\hline
\end{tabular}

\section{Heteroscedasticity Test}

This test is carried out to test whether there is or there is not a deviation of the classic assumption. Heteroscedasticity can be interpreted as the inequality of variants from residuals for all observations in the regression model. If the significance value of independent variables is $>0.05$ then heteroscedasticity does not occur; however, if the value of independent variables is $<0.05$ then heteroscedasticity problem occurs. Based on Table 1.3, using Glejser test, the R-Squared value was 2.7984 with prob. F value of 0.6354 . In heteroscedasticity test, if probabability $>0.05$, it indicates that there is no heteroscedasticity. In this study, the probability value was $0.6354>0.05$, which means that there was no problem of heteroscedasticity.

Table 3 Heteroscedasticity Test

\begin{tabular}{llll}
\hline \multicolumn{4}{l}{ Heteroscedasticity Test: Glejser } \\
\hline F-statistic & 0.644985 & Prob. F(4,26) & 0.6354 \\
\hline Obs ${ }^{*}$ R-squared & 2.798403 & Prob. Chi-Square (4) & 0.5921 \\
\hline Scaled explained SS & 2.937900 & Prob. Chi-Square (4) & 0.5683 \\
\hline
\end{tabular}




\section{Multiple Linear Regression Analysis}

Table 4 The Results of Multiple Linear Regression Equation

\begin{tabular}{|c|c|c|c|c|}
\hline Variable & Coefficient & Std. Error & t-Statistic & Prob. \\
\hline $\mathrm{C}$ & -26.66654 & 5.806775 & -4.592314 & 0.0001 \\
\hline GOLD PRICE (X1) & 1.360151 & 0.370853 & 3.667624 & 0.0011 \\
\hline WORLD OIL (X2) & 0.409938 & 0.120356 & 3.406044 & 0.0022 \\
\hline EXCHANGE RATE (X3) & 2.382032 & 0.480602 & 4.956352 & 0.0000 \\
\hline INFLATION (X4) & 0.019142 & 0.051999 & 0.368126 & 0.7158 \\
\hline R-squared & 0.807095 & \multicolumn{2}{|c|}{ Mean dependent var } & 7.406636 \\
\hline Adjusted R-squared & 0.777417 & \multicolumn{2}{|c|}{ S.D. dependent var } & 0.155871 \\
\hline S.E. of regression & 0.073538 & \multicolumn{2}{|c|}{ Akaike info criterion } & -2.235335 \\
\hline Sum squared resid & 0.140604 & \multicolumn{2}{|c|}{ Schwarz criterion } & -2.004046 \\
\hline Log likelihood & 39.64769 & \multicolumn{2}{|c|}{ Hannan-Quinn criter. } & -2.159940 \\
\hline F-statistic & 27.19526 & \multicolumn{2}{|c|}{ Durbin-Watson stat } & 1.572762 \\
\hline Prob(F-statistic) & 0.000000 & & & \\
\hline
\end{tabular}

Source: Eviews Output Results, 2019

Based on Table 4, the processed data yielded a multiple linear regression model as follows:

$\log Y=-26,6665+1,3601+0,4099+2,3820+0,0191$

The results of multiple linear regression can be summarized as follows:

a. Regression coefficient of world gold price (X1) had a significant positive effect with the coefficient of 1.3601 . This implies that, if world gold price increased by $1 \%$, mining stock index would increase by $1.36 \%$.

b. Regression coefficient of world oil price (X2) had a significant positive effect with the coefficient of 0.4099 . This implies that, if world oil price increased by $1 \%$, mining stock index would increase by $0.41 \%$.

c. Regression coefficient of exchange rate (X3) had a significant positive effect with the coefficient of 2.3820 . This implies that, if exchange rate increased by $1 \%$, mining stock index would increase by $2.38 \%$.

d. Regression coefficient of inflation (X4) had a positive but not significant effect on mining stock index with the coefficient of 0.0191 . This implies that, if inflation increased, it would not affect mining sector stock price.

\section{Coefficient of Determination $\left(\mathbf{R}^{2}\right)$}

This test is used to see how much independent variable affects dependent variable. $R^{2}$ can be said to be good if it is above 0.5 because the value of $R^{2}$ ranges from 0 to $1\left(0<R^{2}<1\right)$. Based on Table 1.4 , the R-Squared value was 0.8070 which means that $80.70 \%$ of mining stock index was influenced by world gold price (X1), world oil price (X2), exchange rate of rupiah to US dollar (X3) and inflation (X4), while $19.3 \%$ was influenced by other variables outside the model.

\section{Discussion}

The result of this study showed that the world gold price variable had a significant positive effect on mining stock index in Indonesia. This is due to the fact that when gold price increases it will increase stock price index, so the returns obtained will also increase. When the price of gold begins to rise, the public will shift to invest in gold, which makes mining sector companies gain more profit from the sale of gold, then mining stock price index also increases and the returns obtained are also getting bigger. In addition, this is because gold is still an investment choice for the community. When world gold price increases, mining stock index will increase. This is in accordance with a study conducted by (Kurniawan ,2013), (Darmawan, 2018), (Kesuma, 2012), (Purnamasari, 2017) and (Yunita et al., 2018) which found that world gold price influenced mining stock index in Indonesia. 
Based on the result of the study, world oil price variable had a significant positive effect on mining stock index in Indonesia. This means that the increase in world oil price will push up mining sector stock price. The result of this study supports the study conducted by (Kilian, 2007) and (Bjornland ,2008). (Kesuma, 2012) and (Hutapea, 2014) in their study also found that world oil price had a significant positive effect on mining stock index.

In addition, this study found that the exchange rate variable had a significant positive effect on mining stock index in Indonesia. This is due to the depreciation of domestic currency, which indicates the weakening of the economy of a country so as to provide an unfavorable effect on capital market. The occurrence of exchange rate depreciation in long term will make investors sell their shares because they do not want to experience large losses. The large number of stock sales from mining sector will cause the IHSG to decline. The result of this study is consistent with studies conducted by (Murcia, 2014), (Yunita et al., 2018) and (Kesuma, 2012).

Furthermore, this study discovered that the inflation variable had no effect on mining stock index in Indonesia. This happened because inflation in Indonesia was included in low inflation category because its rate was less than $10 \%$ per year. Investors assume that the economy is still safe and they are still waiting for the government's policy to manage inflation rate. Besides, inflation rate in this study was still in a safe stage. The result of this study is in accordance with a study conducted by (Rohmanda, 2014) and (Sambodo, 2014).

\section{Conclusions}

Based on the tests, data processing and discussion on the effect of macroeconomics and global commodity prices on mining index on Indonesian Stock Exchange for the period of August 2016 February 2019 that have been carried out, some conclusions can be drawn: (1) world gold price has a significant positive effect on mining stock index; (2) world oil price has a significant positive effect on mining stock index; (3) exchange rate has a significant positive effect on mining stock index; and (4) inflation has no effect on mining stock index. In addition, based on the existing limitations, further research is recommended to include countries in ASEAN and use other factors as dependent variables such as Gross Domestic Product (GDP), foreign-exchange reserves, company financial statements, domestic interest rate, fiscal policy and monetary policy from developed countries.

\section{References}

Balasingham, K. (2016). Industry 4.0: Securing the Future For German Manufacturing Companies. Master's Thesis. University of Twente.

Dar, A. B., M, A. S., Bhanja, N., \& Samantaraya, A. (2014). The Relationship Between Stock Prices And Exchange Rates In Asian Markets A Wavelet Based Correlation And Quantile Regression Approach. Journal Of Global Business Research, Vol. 3 No.(February 2018), 2045-4457. Https://Doi.Org/10.1108/SAJGBR-07-2013-0061

Darmadji, Tjiptono, 2006. Pasar Modal Di Indonesia. Edisi Kedua. Penerbit: Salemba Barat

Darmawan, I. A. A. (2018). Pengaruh Ekonomi Makro Dan Harga Komoditas Tambang Dunia Terhadap Indeks Harga Saham Sektor Pertambangan Di Indonesia. Administrasi Bisnis (JAB) |Vol., 56(1).

Handiani, S. (2014). Pengaruh Harga Emas Dunia, Harga Minyak Dunia Dan Nilai Tukar Dolar Amerika/Rupiah Terhadap Indeks Harga Saham Gabungan Pada Periode 2008-2013. Journal Graduate Unpar, 1(1), 85-93.

Hau, H. And Rey, H. (2006), "Exchange Rates, Equity Prices And Capital Flows", Review Of Financial Studies, Review Of Financial Studies, Vol. 19 No. 1, Pp. 273-317 Hutapea, G., Margareth, E., \& Tarigan, L. (2014). 
Hermann, M., Pentek, T., \& Otto, B. (2016). Design Principles forIndustrie 4.0 Scenarios. Presented at the 49th HawaiianInternational Conference on Systems Science.

Kpanie, A. F., \& Esumanba, S. V. (2014). Relationship between stock market performance and macroeconomic variables in Ghana. Business Management and Economics, 2(March), 46-53.

Kurniawan, Yohanes Jhony. 2013. Analisis Pengaruh Tingkat Suku Bunga SBI, Inflasi, Harga Minyak Dunia, Harga Emas Dunia, Kurs Rupiah Terhadap Dollar Amerika, Indeks Nikkei 225 Dan Indeks Dow Jones Terhadap Indeks Harga Saham Gabungan. Jurnal Ekonomi Dan Bisnis. Pp: 120

Madura, Jeff, 2006. Keuangan Perusahaan Internasional. Edisi Kedelapan. Jakarta: Salemba Empat, 2006.

Murcia And Tamayo. 2015. Simulating the Effects of Macroeconomic Activities On The Sectoral Indices Of Philippine Stocks Exchange. Bangkok Proceedings Of Business And Social Sciences Research Conference ISBN: 978-1-92206990-0.

Oseni And Nwosa. 2011. Stock Market Volatility and Macroeconomic Variables Volatility in Nigeria: An Exponential GARCH Approach". Singapore: European Journal of Business and Management ISSN 2222-1905 (Paper) ISSN 2222-2839 Vol 3, No.12, 2011.

Pardede, N., \& Sulasmiyati, R. R. H. S. (2015). Pengaruh Harga Minyak Mentah Dunia, Inflasi, Suku Bunga Harga Saham Sektor Pertambangan Di Asean (Studi Pada Indonesia, Singapura, Dan Thailand Periode Juli 2013 - Desember 2015), 39(1).

Yunita, Y., Nurlita, E., Manajemen, P. S., Ekonomika, F., Kristen, U., \& Wacana, S. (2018). Pengaruh Suku Bunga, Kurs Rupiah, Dan Harga Emas Terhadap Return Harga Saham Sektor Pertambangan Di Bursa Efek Indonesia Yunita, 978-979. 